\title{
Physiological and molecular changes associated with prevention of woolliness in peach following pre-harvest application of gibberellic acid
}

\author{
Camila Pegoraro ${ }^{a}$, Marcio Roggia Zanuzo $^{\text {b }}$, Fábio Clasen Chaves ${ }^{a}$, Auri Brackmann ${ }^{c}$, César Luís Girardi e \\ Luciano Lucchetta $^{d}$, Leonardo Nora ${ }^{a, *}$, Jorge Adolfo Silva ${ }^{a}$, Cesar Valmor Rombaldi ${ }^{a}$

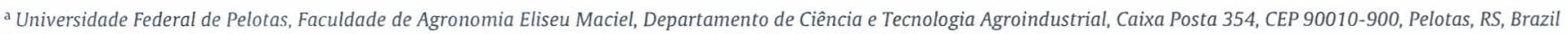 \\ ${ }^{b}$ Universidade Federal de Mato Grosso-Campus Sinop. Av. Alexandre Ferronato, 1200, CEP: 78550-000, Sinop, MT, Brazil \\ ' Universidade Federal de Santa Maria, CEP 97105-900, Santa Maria, RS, Brazil \\ ¿ Universidade Tecnológica Federal do Paraná, CEP 85601-971, Francisco Beltrão, PR, Brazil \\ e Embrapa Uva e Vinho, CEP 95700-000, Bento Gonçalves, RS, Brazil
}

\section{A R T I C L E I N F O}

\section{Article history:}

Received 29 November 2009

Accepted 14 February 2010

\section{Keywords:}

$\mathrm{GA}_{3}$

Prunus persica

Ripening

Cold storage

Controlled atmosphere

Ethylene

Chilling injury

\begin{abstract}
A B S T R A C T
Peach [Prunus persica (L.) Batsch, cv. Chiripá] fruit harvested from plants sprayed with gibberellic acid $\left(\mathrm{GA}_{3}\right)$, at the beginning (T1) and end of pit hardening (T2), kept under cold storage (CS) and controlled atmosphere (CA/CS), and from plants not sprayed with $\mathrm{GA}_{3}$ (Control) and kept under $\mathrm{CS}$, were evaluated in terms of fruit size and mass, ripening, occurrence of woolliness and expression of supposedly related genes and proteins. Peaches not sprayed with $\mathrm{GA}_{3}$ and submitted to CS had a high incidence of woolliness, high mRNA abundance of vesicle transport genes and low mRNA abundance of genes associated with cell wall loosening, ethylene biosynthesis and heat shock proteins (HSPs). Early $\mathrm{GA}_{3}$ spraying did not delay ripening but induced an increase in fruit size. In addition, it also induced a climacteric rise and prevented the occurrence of woolliness after CS. Woolliness prevention as a result of either $\mathrm{GA}_{3}$ or CA/CS treatments resulted in higher abundance of mRNAs associated with cell wall metabolism, mitochondrial HSPs and 1aminocyclopropane-1-carboxylic acid oxidase $(A C C O)$. A unique $\mathrm{GA}_{3}$ response consisted of a high mRNA abundance of genes and/or proteins such as HSP40-1er, HSP40-2er, HSPCTR2, $\beta$-mannosidase ( $\beta$-Man) and $\alpha$-L-arabinofuranosidase ( $\alpha$-Ara).
\end{abstract}

(C) 2010 Elsevier B.V. All rights reserved.

\section{Introduction}

Chiripá peach [Prunus persica (L.) Batsch], a late maturing cultivar grown in Southern Brazil, yields medium size white melting flesh fruit highly appreciated by consumers. The fruit is harvested in summer, from mid December through mid January, and requires cold storage (CS) to achieve an extended shelf-life. However, the occurrence of woolliness due to a prolonged period of CS is an important constraint for Chiripá peach growers (Rombaldi et al., 2002; Girardi et al., 2005). Woolliness occurs in almost all melting flesh cultivars of peach and nectarine [P. persica (L.) Batsch var. nucipersica (Suckow) C.K. Schneid], and the prevention of this disorder is essential in order to maintain their marketability (Lurie and Crisosto, 2005; González-Agüero et al., 2008). This chilling injury, characterized by loss of juiciness, has been associated with abnormal cell wall disassembly during ripening (Zhou et al., 2000; Brummell et al., 2004; Girardi et al., 2005; Lurie and Crisosto, 2005; González-Agüero et al., 2008). Normal peach fruit

\footnotetext{
* Corresponding author. Tel.: +55 533275 7258x217; fax: +55 533275 7258x200. E-mail address: leonardo@ufpel.edu.br (L. Nora).
}

ripening involves a series of cell wall modifications and increased transcription of genes encoding proteins and enzymes associated with the functionality of the endomembrane system (Trainotti et al., 2003; González-Agüero et al., 2008). Recently, González-Agüero et al. (2008) identified a set of genes differentially expressed in juicy and woolly peaches, including genes putatively involved in intracellular trafficking and cell wall metabolism that were repressed in woolly fruit. In addition, Vizoso et al. (2009) found differential expression of genes associated with plastids, mitochondria, endoplasmic membrane and ribosomes when comparing woolly and juicy fruit. Ogundiwin et al. (2008) also found genes controlling chilling injury differentially expressed between juicy and woolly fruit. In woolly fruit, commonly stress-induced genes, ripeningrelated genes and genes involved in amino acid transport were up-regulated, while HSPS genes were down-regulated.

The use of controlled atmosphere (CA/CS), intermittent warming, or ethylene treatment during CS are effective measures in preventing woolliness in Chiripá peach (Girardi et al., 2005). However, in contrast to CA/CS, the use of intermittent warming or ethylene during storage results in a high incidence of fruit decay (50\% and 25\%, respectively) (Girardi et al., 2005). One strategy for extending the period of fruit availability and shelf-life is to 
delay the ripening process. For example, $\mathrm{GA}_{3}$ has been shown to delay ripening in peach (Ju et al., 1999; Martinez-Romero et al., 2000; Amarante et al., 2005), nectarine (Zilkah et al., 1997), persimmon (Diospyros kaki Thunb.) (Ben-Arie et al., 1996; Ferri et al., 2004), tangerine (Citrus reticulata Blanco) (Marur et al., 1999) and strawberry (Fragaria annanassa Duch.) (Martínez et al., 1994) fruit. Responses to $\mathrm{GA}_{3}$ action seem to vary according to the species and cultivar involved. $\mathrm{GA}_{3}$ can induce hydrolytic cell wall enzymes, enhancing polysaccharide solubilization and favouring cell expansion (Thomas et al., 2005). $\mathrm{GA}_{3}$ is also involved in the protection of the endomembrane system, regulating genes involved in its own biosynthetic pathway, or acting in cell wall disassembly (Hu et al., 2008). In other cases, $\mathrm{GA}_{3}$ inhibits chlorophyll breakdown (Rosenvasser et al., 2006) and delays the onset of climacteric respiration (Ben-Arie et al., 1996) and the ripening cycle (Ferri et al., 2004). In addition, previous studies have indicated the stage of pit development as being pivotal in achieving physiological responses with the application of plant growth regulators such as $\mathrm{GA}_{3}$ (Zilkah et al., 1997; Ju et al., 1999; Amarante et al., 2005)

The current study tested whether $\mathrm{GA}_{3}$ application at a definite stage of pit development is effective in increasing fruit size and mass, delaying the ripening cycle, and preventing woolliness in Chiripá peaches. Moreover, in order to gain further understanding of the molecular mechanisms associated with these physiological changes, the relative mRNA abundance of genes putatively associated with cell wall metabolism, intracellular trafficking, heat shock proteins and ethylene synthesis, as well as the expression of a set of proteins involved in cell wall metabolism and ethylene, synthesis were investigated.

\section{Materials and methods}

\subsection{Plant muterial and experimental design}

A preliminary study (2006) was performed on a 6-year-old commercial peach $[P$. persica (L.) Batsch $\mathrm{CV}$. Chiripá] orchard, planted in Farroupilha, Southern Brazil. In order to evaluate the effects of gibberellic acid $\left(\mathrm{GA}_{3}\right)$ on fruit growth and ripening, three replicates of twenty trees, selected based on size uniformity, were treated as follows: Control-without $\mathrm{GA}_{3}$; T1-spraying $400 \mathrm{~L} \mathrm{ha}^{-1}$ of a $\mathrm{GA}_{3}$ solution $\left[50 \mathrm{mg} \mathrm{L}^{-1}\right.$ of $\mathrm{GA}_{3}$ (Proggib ${ }^{\circledR}$ ) and surfactant $(0.05 \%, v / v)\left(\right.$ Silwet $\left.^{\circledR}\right), \mathrm{pH} 4.5$ ] at the beginning of the pit hardening stage (45 days after anthesis, DAA); and T2-spraying $400 \mathrm{Lha}^{-1}$ of the same $\mathrm{GA}_{3}$ solution at the end of the pit hardening stage (75 DAA). A similar stage characterization has been applied in previous studies (Zilkah et al., 1997; Ju et al., 1999; Amarante et al., 2005). For each treatment, $84 \mathrm{~kg}$ of peach (12 boxes with $7 \mathrm{~kg}$ of fruit) were harvested when fruit colour was light green, corresponding to the pre-climacteric stage, between S3 I and S3 II, as described by Trainotti et al. (2003). Fruit were evaluated in terms of size (equatorial circumference), mass, skin colour, flesh firmness, soluble solids content (SSC), and ethylene production, and then cold stored at $1.0{ }^{\circ} \mathrm{C}( \pm 1.0 \mathrm{C}), 92.0 \%$ $( \pm 5.0 \%)$ relative humidity $(\mathrm{RH})$ for 30 days. Finally, the fruit were exposed to $23.0 \mathrm{C}\left( \pm 3.0^{\circ} \mathrm{C}\right)$ and $75.0 \%( \pm 5.0 \%) \mathrm{RH}$ for 2 days then evaluated for woolliness occurrence. Fruit that upon hand squeezing did not release any juice were considered woolly. For a detailed description of each analysis refer to Girardi et al. (2005).

A second experiment was carried out in the following year (2007), in which Control (without $\mathrm{GA}_{3}$ ) and T1 $\left(\mathrm{GA}_{3}\right.$ sprayed at the beginning of pit hardening) treatments were applied following the same experimental design on the same set of plants. At harvest, $168 \mathrm{~kg}$ of peach (24 boxes with $7 \mathrm{~kg}$ of fruit) from Control and $84 \mathrm{~kg}$ of peach (12 boxes with $7 \mathrm{~kg}$ of fruit) from T1 were collected. Half of the Control fruit were kept under CS (Control CS) and the other half under controlled atmosphere (Control CA/CS) at $2 \mathrm{kPa}$ of $\mathrm{O}_{2}$, $5 \mathrm{kPa}$ of $\mathrm{CO}_{2}, 1.0^{\circ} \mathrm{C}\left( \pm 1.0^{\circ} \mathrm{C}\right)$ and $92.0 \%( \pm 5.0 \%) \mathrm{RH}$ (same temperature and humidity used for CS), while T1 fruit were stored under CS only (T1 CS). After 30 days of storage under CS or CA/CS conditions, fruit were exposed to $23.0^{\circ} \mathrm{C}\left( \pm 3.0^{\circ} \mathrm{C}\right)$ and $75 \%( \pm 5 \%) \mathrm{RH}$, for $6 \mathrm{~h}, 2$, 4 and 6 days and then evaluated for mRNA and protein abundance, ethylene production and occurrence of woolliness.

The experiments were performed in a completely randomized design. Percentage data was normalized according to the equation $f(x)=$ arcsine $\sqrt{ } X$. ANOVA was performed using the $F$-test at the $5 \%$ significance level. Means of treatments were compared using Duncan's test at the 5\% significance level. SANEST (Zonta and Machado, 1991) was used to perform statistical analyses.

\subsection{Quantitative real-time $P C R(q-P C R)$}

RNA was extracted from peach flesh following the protocol described for PureLinK ${ }^{\mathrm{TM}}$ reagent (Plant RNA Reagent-Invitrogen ${ }^{\mathrm{TM}}$ ). Total RNA was treated with DNAse I-Invitrogen ${ }^{\mathrm{TM}}$ and each sample was reverse-transcribed into cDNAs using the commercial kit SuperScript First-Strand System for $R T-P C R$ (Invitrogen ${ }^{\mathrm{TM}}$ ). The quantity and quality of the RNA and cDNA was assessed spectroscopically and by electrophoresis in agarose gel.

Genes from peach, tomato (Lycopersicon esculentum Mill.) and arabidopsis [Arabidopsis thaliana (L.) Heynh.] putatively encoding proteins involved in cell wall metabolism, intracellular trafficking, heat shock proteins, and ethylene synthesis were selected based on previous work that showed an association between these metabolic functions and woolliness (Pratt and Toft, 2003; Trainotti et al., 2003, 2006; González-Agüero et al., 2008; Iwata et al., 2008; Mueller et al., 2008; Su and Li, 2008). Gene-specific primers were designed from sequences deposited in the GeneBank (Benson et al., 2005) using Vector NTI Advance ${ }^{\mathrm{TM}} 10$ (Invitrogen, 2005). The criteria used for primer selection consisted of amplicon size between 100 and 150 bp, CG content between $40 \%$ and $60 \%, 3^{\prime}$ ends with less than two $C$ and $G$ bases in the last five nucleotides and melting temperature ranging from 60 to $65^{\circ} \mathrm{C}$ according to Applied Biosystems ${ }^{\circledR}$ recommendations. The sizes of amplification products and their specificity were tested in agarose gels $(2 \%, \mathrm{w} / \mathrm{v})$ prior to q-PCR. Melting curves were evaluated and only primers giving single peaks were used (Table 1 ). q-PCR was performed with a 7500 Real-Time PCR System (Applied Biosystems ${ }^{\circledR}$ ) using SYBR ${ }^{\circledR}$ Green. The amplification reaction was carried out in a total volume of $25 \mu \mathrm{L}$, containing $2 \mu \mathrm{M}$ of each primer, $12.5 \mu \mathrm{L}$ of PCR Master Mix SYBR ${ }^{\circledR}$ Green, $1 \mu \mathrm{L}$ of cDNA (diluted 5 -fold) and water to make up the final volume. Samples were loaded in 96 well optic plates (Applied Biosystems ${ }^{\circledR}$ ) and covered with optic adhesives (Applied Biosystems ${ }^{\circledR}$ ). Thermal cycle conditions were as follows: denaturing at $50^{\circ} \mathrm{C}$ for $2 \mathrm{~min}$ and $95^{\circ} \mathrm{C}$ for $10 \mathrm{~min}$, followed by 40 three-step cycles ( $95^{\circ} \mathrm{C}$ for $30 \mathrm{~s}, 57^{\circ} \mathrm{C}$ for $1 \mathrm{~min}$ and $72^{\circ} \mathrm{C}$ for $1 \mathrm{~min}$ ) and final extension at $72{ }^{\circ} \mathrm{C}$ for $5 \mathrm{~min}$. Relative quantification of each single gene expression was performed using the comparative threshold cycle method, as described by Livak and Schmittgen (2001). For each cDNA, $18 S$ was used as a reference gene to quantify cDNA abundance (at the same dilution as mentioned above). Threshold cycle (CT) was calculated based on the PCR exponential reaction obtained from the relative expression level (REL) formula, $R E L=2^{-\Delta \Delta C T}$. Results were expressed as mRNA abundance in a colour diagram using the Multi Experiment Viewer (TIGR MeV) software (Saeed et al., 2003). mRNA abundance of each gene from Control CS fruit at $6 \mathrm{~h}$ served as the baseline for determining relative RNA levels. 
Table 1

Specific primers used for quantitative PCR analysis of target genes.

\begin{tabular}{|c|c|c|c|}
\hline Genes & GI & Forward & Reverse \\
\hline \multicolumn{4}{|l|}{ Ethylene synthesis } \\
\hline 1-Aminocyclopropane-1-carboxylate oxidase (ACCO) & 33329719 & GGATTGGGAGCTTGCTTGCAA & TTGCAAGCCCGTGAGATGAT \\
\hline \multicolumn{4}{|l|}{ Cell wall metabolism } \\
\hline Cobra $(\mathrm{Cob})$ & 22478530 & ACTCATCCAGGAAGCTGTGTAG & ATGGCTGTATCATTTATTGTCGCA \\
\hline Glucan Synthase (GLS) & 22478796 & TGGGAAACATGGTGGTATGAGGA & CGA GACATTTGAAGTGAGTGAAC \\
\hline Galactosyl transferase (GalT) & 22480478 & ATGTGAAAAGTGGATGCGGAA TG & TTGGATGAGAAGCGGGAAGAGA \\
\hline Cinnamoyl-CoA reductase $(C C R)$ & 22481300 & ATCAAGTCCAAGACCCCGAGAA & CGCCCAACACGGTGCCAGGA \\
\hline Pectate lyase $(P L)$ & 22483439 & GCCTTGCCGTACGCTCATGTC & CTTCAGCCTCAACCCCTTCCCT \\
\hline Endopolygalacturonase $(P G)$ & 110293962 & AAAGGGTGCCCTGGTCAGGTAAGATA & GCTCTTCTAGGTGGAAGCCCAAGAAA \\
\hline Pectin methylesterase (PME) & 1213628 & AGGTGGCCTCCATTCTCTCTCAGTT & GGGAAGCAGAGAGAGACCAGTTCAA \\
\hline Beta-galactosidase $(\beta$-Gal) & 157313305 & CGTGTATGGGGCATTGGAGAA & CTCCCGCATTCCATGTCTCAA \\
\hline Endo-1,4-beta-mannosidase ( $\beta$-Man $)$ & 157313309 & ACAAGGTTTTCCCATCCATGTTGAA & ATGGGTCAGAAGCCACATACATCAA \\
\hline Alpha-L-arabinofuranosidase $(\alpha-A r a)$ & 145338352 & ACСTCСACTССТССТСTGTCTGATT & TTCTGAGCAACTTCCAAGACTCCAT \\
\hline Expansin $1($ Exp 1$)$ & 16305104 & AAACGTTGGTGGTGCCGGTGAT & TTGCTTGCCAACCAGTCCTGGA \\
\hline $\operatorname{Exp2}$ & 29466640 & TCCAGGACTGGTTGGCAAGCAA & TAGGACACCACTGTGCGGCCAT \\
\hline Exp3 & 29466642 & GGGTGCATGGGAAGCAGCTCAT & CCATGGTGCCAGAGGCATCAGA \\
\hline Exp4 & 21901947 & TGAGCTGTGGGGCATGCTATGA & AGGATCACACCAGCCACCTGGT \\
\hline \multicolumn{4}{|l|}{ Endomembrane transport } \\
\hline Golgi transport protein SFT2-like (SFT2) & 22481199 & CACTCA AAGGCCCGAAGAATCA & CAACGTCACCTCCCAAAACATC \\
\hline SNARE-like protein (Vap27-2) & 22481415 & CCAAAGAAATACTGCGTGCGGC & GGAAGAGGGTGGGCTGATGAG \\
\hline Dynamin-like protein $1 A(A D L 1 A)$ & 22481576 & GTGAACAAAATCCAAAGAGCTTG & GCCAGTTTCTCGATCTGTCTC \\
\hline ROC7 cyclophilin (ROC7) & 22481624 & CCAGGCAAA GAAGTCAAAGGAG & TCACCTCCCTGAATCATGAAACT \\
\hline Rab GTP-binding protein (Rab5) & 22482805 & CCATAGGTGCTGCCTTCTICTC & CCATGTTIGGATTGCCTTGTGATT \\
\hline Vesicle-associated membrane protein 722 (Vamp) & 22483019 & GCAAAGCAGGTGGTCTCAGG & TTAAGGCTATTGGCAGGGGCT \\
\hline Kinesin (Kin) & 51560894 & ATCAAACGACCAAAGCGGGCTTA & AATTTCGCCACGAGAACCCACAT \\
\hline Clathrin-binding protein b-adaptin (Cla) & 22483877 & CTTGGTGATCTGATTGGCATGG & ACTIGTGGAACCTGAAGGGGTC \\
\hline Syntasin (Syn) & 56162812 & CTGTGCAAGCTACCTCCCACCTT & GATCACTGCTCAAGCCACCACAA \\
\hline ER lumen protein retaining receptor 2 (ERD2) & 22477673 & GCCAGTATTTTGGTCCTCCTTC & TCTTGAAATGTGAATTCCTCGTG \\
\hline RabGTP-binding protein (Rab11) & 22484722 & ATGTTTGTAGGTTATTAGTCGCTTA & CGCTCTTGACCAGTTGTATCCCA \\
\hline \multicolumn{4}{|l|}{ Heat shock proteins (HSPS) } \\
\hline HSP40-1 er resident (HSP40-1er) & 186512089 & TGCACCTCGCCTGCTTGAAGAT & TTGCGGGGTATAACGGCCATCT \\
\hline HSP7Oer & 240254046 & CCGCGGTCCAAGGTGGAGTATT & TCAAAGGCGCAACATCAAGCAG \\
\hline HSP40-2er & 79318135 & CGCCAGCAGCTTCTGCACACAA & TTCTCCGTCGAGCCACGCAAAT \\
\hline HSP calnexin 1 (HSPCNX1) & 145359541 & TGTCCTCGTCGCCATTGTGGTT & CTTCTITTCCACAGGTGCCGCC \\
\hline HSP calreticulin 2 (HSPCRT2) & 145335312 & TCTCCTCGCGGTATATATAAGC & AGACGAGGCTAGGAATCATTIT \\
\hline HSP70 chloroplast resident (HSP7OCh) & 145359060 & CCAACCTCCGCCTICCTTCGTA & ACCAACGGTGTATCGGGAAGCG \\
\hline HSP17.8ch & 30680121 & CCGAGTCACCAGCTITGCTCAGAA & TGTTGTTGCCGAAGAAGCTTGGAA \\
\hline HSP60 mitochondria resident (HSP60mi) & 20466255 & ACCTCGCCTCCAAGGCAAGGAT & TTCTGCTGGAAACCTGGCGAGC \\
\hline HSP26.5mi & 186490445 & CAATGGCTCTAGCTCGTCTGGCTTT & TTCACCAGCCGAAGTAGCCATGAAT \\
\hline HSP60-3Bmi & 145338881 & CCTCGCCTCCAAGGCAAGGATT & TTCTGCTGGAAACCTGGCGAGC \\
\hline \multicolumn{4}{|l|}{ Endogenous control } \\
\hline 185 & 66627320 & AAAACGACTCTCGGCAACGGATA & ATGGTTCACGGGATTCTGCAATT \\
\hline
\end{tabular}

\subsection{Protein immunodetection}

Immunodetection of proteins was performed by Western blotting using mouse polyclonal antibodies produced against the recombinant proteins endopolygalacturonase (anti-PG, gi110293962), pectin methylesterase (anti-PME, gi1213628), $\beta$-galactosidase (anti- $\beta-G a l$, gi157313305), pectate lyase (anti-PL, gi22483439), endo-1,4- $\beta$-mannase (anti- $\beta$-Man, gi157313309) and $\alpha$-arabinofuranosidase (anti- $\alpha$-Ara, gi145338352) expressed by vector pAE (Ramos et al., 2004) and ACC oxidase (antiACCO, gi33329719) as previously described by Rombaldi et al. (1994). Frozen peach flesh $(3.0 \mathrm{~g})$ was ground into powder and extracted with a solution containing $1.5 \mathrm{~mL}$ of $280 \mathrm{mM}$ Tris- $\mathrm{HCl}$ ( $\mathrm{pH} 8.3), 0.5 \mathrm{M}$ DTT, glycerol $(20 \%, \mathrm{v} / \mathrm{v})$ and SDS $(4 \%, w / v) . \beta-$ Mercaptoethanol $(10 \%, v / v)$ was added just before heating the samples at $80^{\circ} \mathrm{C}$ for $10 \mathrm{~min}$. Samples were then cooled at $4{ }^{\circ} \mathrm{C}$ and centrifuged at $14,000 \times \mathrm{g}$ for $30 \mathrm{~min}$. Protein quantification was performed according to Bradford's (1976) method following precipitation with trichloroacetic acid and solubilization with $0.1 \mathrm{M}$ sodium hydroxide. Equal amounts of total protein $(30 \mu \mathrm{g})$ were loaded per gel slot onto a denaturing, $1 \mathrm{~mm}$ thick, polyacrylamide ge $(12 \%, w / v)$, according to Sambrook et al. (1989), and run for $30 \mathrm{~min}$ at $90 \mathrm{~V}$ followed by $1 \mathrm{~h}$ at $150 \mathrm{~V}$. Proteins were transferred from the polyacrylamide gel to a nitrocellulose membrane (Hybond ECL, GE Healthcare ${ }^{\circledR}$ ) using a gel blotter (Bio-Rad), at
$4{ }^{\circ} \mathrm{C}\left( \pm 2^{\circ} \mathrm{C}\right)$. The efficacy of the transfer was monitored by colour using Ponceau's reagent. The membrane was washed with a Trisbuffered saline Tween solution [TBS-T, $20 \mathrm{mM}$ Tris, $137 \mathrm{mM} \mathrm{NaCl}$ and Tween-20 $(0.1 \%, v / v), \mathrm{pH} 7.6$ ] for $1 \mathrm{~h}$ at room temperature (RT) with agitation and blocked with ECL Advance Blocking ${ }^{\circledR}$ agent ( $2 \%$, $w / v$ ) in TBS-T. Primary antibodies were diluted in TBS-T at 1:2000 (anti- $\beta-M a n$ and anti- $\alpha$-Ara), 1:5000 (anti-PL, anti- $\beta-$ Gal and anti-ACCO) and 1:10,000 (anti-PG and anti-PME) and incubated for $1 \mathrm{~h}$ at RT. Membranes were washed three times for 10 min with TBS-T and incubated for $1 \mathrm{~h}$ at RT with a 1:50,000 dilution of the peroxidase-labelled rabbit anti-mouse antibody (GE Healthcare ${ }^{\circledR}$ ). Membranes were then washed with water and developed using the GE Healthcare ${ }^{\circledR}$ Kit (ECL Advance Western ${ }^{\circledR}$ blotting detection reagents), with an exposure time of about $10 \mathrm{~s}$.

\subsection{Preparation of antibodies}

Total RNA was extracted from $50 \mathrm{mg}$ of flesh from Chiripá peach at S1, S2, S3 and S4 ripening stages using Concert Plant RNA Reagent (Invitrogen, USA, catalogue \# 12323-012) to produce polyclonal antibodies. The RNAs were mixed and $5 \mu \mathrm{g}$ was reverse-transcribed using SuperScript ${ }^{\mathrm{TM}}$ III First-Strand Synthesis System for RT-PCR (Invitrogen, USA, catalogue \# 18080-051).

The first strand cDNA was amplified using forward primers including a Bam $\mathrm{HI}$ restriction site and reverse primers including a 
Table 2

Characteristics of Chiripá peach fruit, immediately after harvest from trees sprayed with $\mathrm{GA}_{3}$ at the beginning (T1) and end (T2) of pit hardening, and from untreated trees (Control) $)^{\mathrm{a}, \mathrm{b}}$

\begin{tabular}{lllllll}
\hline Treatment & $\begin{array}{l}\text { Fruit equatorial } \\
\text { circumference } \\
(\mathrm{cm})\end{array}$ & Fruit mass (g) & $\begin{array}{l}\text { Fruit colour (hue } \\
\text { angle) }\end{array}$ & $\begin{array}{l}\text { Flesh firmness } \\
(\mathrm{N})\end{array}$ & $\begin{array}{l}\text { Soluble solids } \\
\text { content (\%) }\end{array}$ & $\begin{array}{l}\text { Ethylene } \\
\text { production } \\
\left(\mathrm{nLg}^{-1} \mathrm{~h}^{-1}\right)\end{array}$ \\
\hline Control & $19.14 \mathrm{~b}^{\mathrm{c}}$ & $102.12 \mathrm{~b}$ & $98.12 \mathrm{a}$ & $50.25 \mathrm{a}$ & $12.01 \mathrm{a}$ & $1.26 \mathrm{a}$ \\
T1 & $26.80 \mathrm{a}$ & $150.14 \mathrm{a}$ & $102.01 \mathrm{a}$ & $48.14 \mathrm{a}$ & $11.82 \mathrm{a}$ & $1.09 \mathrm{a}$ \\
T2 & $18.15 \mathrm{~b}$ & $100.04 \mathrm{~b}$ & $100.07 \mathrm{a}$ & $52.25 \mathrm{a}$ & $12.23 \mathrm{a}$ & $\mathbf{1 2 . 3 \mathrm { a }}$ \\
\hline
\end{tabular}

a The peaches were harvested when the fruit colour was light green, corresponding to the pre-climacteric stage, between S3 I and S3 II, described by Trainotti et al. (2003).

b Three replicates of ten trees, selected based on size uniformity, were treated as follows: Control-without $\mathrm{GA}_{3}$; $\mathrm{T}_{1-\mathrm{spraying}} 400 \mathrm{~L}^{-1}$ of a $\mathrm{GA}_{3}$ solution [ $50 \mathrm{mg} \mathrm{L}^{-1}$ of

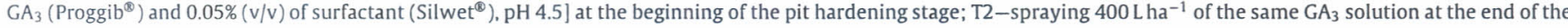
pit hardening stage.

Means of treatment followed by different letters are statistically different according to Duncan's test $(p \leq 0.05)$. For the variates fruit equatorial circumference, fruit mass, fruit colour, flesh firmness, soluble solids content and woolly fruit, $n=120$, and for the variate ethylene production, $n=3$.

KpnI restriction site and also the stop codons TGA and TCA. PCR conditions were: denaturing at $95^{\circ} \mathrm{C}$ for $3 \mathrm{~min}$, followed by 30 cycles at $95 \mathrm{C}$ for $1 \mathrm{~min}$, annealing at $55 \mathrm{C}$ for $1 \mathrm{~min}$ and extension at $72{ }^{\circ} \mathrm{C}$ for $90 \mathrm{~s}$, followed by one cycle at $72^{\circ} \mathrm{C}$ for $10 \mathrm{~min}$. Fragments amplified by PCR were purified using GFX ${ }^{\mathrm{TM}}$ PCR DNA system and $\mathrm{Gel}$ Band Purification system (Amersham Bioscience ${ }^{\circledR}$ ) and analyzed by electrophoreses in agarose gel $(0.8 \%, w / w)$. The purified product was sequenced (Applied Biosystems Automated 3730 DNA Analyzer), cloned using the vector pCR2.1-TOPO-TA (Invitrogen ${ }^{\circledR}$ ) and transfer 'ed to the expression vector pAE (Ramos et al., 2004). Each cloning was carried out in duplicate and resequenced prior to Escherichia coli BL21 pLyss transformation. Recombinant proteins were affinity-purified on a HisTrap column ÄKTA prime (Amersham Biosciences ${ }^{\circledR}$ ) then inoculated into mouse to obtain the polyclonal antibodies. A solution containing $100 \mu \mathrm{g}$ of each purified protein in $0.05 \mathrm{~mL}$ of sterile $200 \mathrm{mM}$ phosphate buffer ( $\mathrm{pH} \mathrm{8.0),} \mathrm{contain-}$ ing $\mathrm{NaCl} 0.5 \mathrm{M}$ and imidazole $0.005 \mathrm{M}$ was mixed with aluminium hydroxide $(15 \%, \mathrm{v} / \mathrm{w})$ prior to intramuscular injection. The second dose was given 21 days later. Serum was collected 63 days after the second injection and immunopurified against the respective recombinant proteins. The specificity and sensitivity of the antibodies was tested against recombinant proteins and total peach protein extracts from the S1, S2, S3 and S4 ripening stages. Antibodies recognized their recombinant protein and reacted specifically with one or few background bands in $30 \mu \mathrm{g}$ of total peach proteins. Antibody recognition occurred at the same conditions of Western blot, 0.005 pg of recombinant PME, PG, $\beta$-Gal, PL, ACCO and $0.025 \mathrm{pg}$ of $\beta$-Man and $\alpha$-Ara protein.

\section{Results}

In order to extend the ripening cycle and increase fruit size, Chiripá peaches were treated with gibberellic acid $\left(\mathrm{GA}_{3}\right)$ at the beginning and end of the pit hardening stage. Pre-harvest $\mathrm{GA}_{3}$ spray did not delay fruit ripening (Table 2). Fruit from all treatments reached the same ripening stage at the same time without showing any differences in colour (hue angle from 98.12 to 102.01), flesh firmness (ranging from 48.14 to $52.25 \mathrm{~N}$ ), soluble solids content (ranging from $11.82 \%$ to $12.23 \%$ ) or ethylene production. At harvest, fruit underwent pre-climacteric ripening equivalent to the S3 l or S3 II stage (Trainotti et al., 2003), with low ethylene production ranging from 0.86 to $1.26 \mathrm{nLg}^{-1} \mathrm{~h}^{-1}$. Pre-harvest spraying of $\mathrm{GA}_{3}$ at the beginning of pit hardening (T1) resulted in a significant increase in fruit size and mass compared to untreated fruit (Control), leading to a $47 \%$ gain in productivity per plant. However, postponing $\mathrm{GA}_{3}$ application to the end of pit hardening (T2) did not contribute to an increase in fruit size or mass.

Larger fruit, from the early $\mathrm{GA}_{3}$ treatment (T1), had a lower incidence of woolliness when compared to untreated fruit (Control) or the late $\mathrm{C}_{2} \mathrm{~A}_{2}$ treatment (T) (Tahle )) Inridenre of umollinner in peach from the Control treatment (without $\mathrm{GA}_{3}$ ) was high after 30 days of cold storage (CS), reaching $85 \%$ of the fruit after 2 days of ripening at room temperature. In contrast, fruit that received $\mathrm{GA}_{3}$ treatment at the beginning of pit hardening (T1) and after 30 days of CS had lower levels of woolliness (12.3\%). However, woolliness incidence in peaches treated with $\mathrm{GA}_{3}$ at the end of pit hardening (T2) did not differ statistically from the untreated control.

Storage under controlled atmospheres (Control CA/CS), as expected, prevented woolliness (Table 3 ). Woolliness occurrence in $\mathrm{GA}_{3}$-treated peach in cold storage (T1 CS) was as low as $29 \%$ and did not differ statistically from that in untreated peaches stored under CA/CS. The highest percentage of woolly fruit (94.2\%) was observed in untreated peaches stored at low temperature during the second and fourth days of ripening. Upon extension of the ripening period, woolly fruit became juicy again.

Fruit from treatments with lower occurrence of woolliness (Control CA/CS and T1 CS) developed classical climacteric behaviour during ripening, while fruit with a high occurrence of woolliness (Control CS) did not develop climacteric production of ethylene (Table 4).

In order to assess the effects of pre-harvest $\mathrm{GA}_{3}$ treatment and storage under $\mathrm{CA} / \mathrm{CS}$ on woolliness prevention, mRNA abundance of a set of 36 genes associated with cell wall structure and disassembly (14 genes), intracellular transport (11 genes), heat shock proteins (10 genes) and ethylene biosynthesis (1 gene) were studied (Fig. 1).

T1 CS and Control CA/CS peaches had higher relative mRNA abundance of expansins (Exp1, Exp2 and Exp3), PME, PG, PL, $\beta$-Gal, $\beta$-Man and heat shock proteins (HSP40-1er, HSP40-2er, HSP70er, HSPCNX1, HSP17.8ch, HSP60mi, HSP60-3Bmi and HSP26.5mi) than Control CS peaches.

\section{Table 3}

Woolliness incidence in Chiripá peach fruit, harvested from untreated trees (Control) and from trees sprayed with $\mathrm{GA}_{3}$ at the beginning of pit hardening (T1), stored for 30 days, under cold storage (CS) or controlled atmosphere (CA/CS), and finally exposed to $23.0^{\circ} \mathrm{C}\left( \pm 3.0^{\circ} \mathrm{C}\right)$ and $75.0 \%( \pm 5.0 \%) \mathrm{RH}$ for $6 \mathrm{~h}, 2,4$ and 6 days $^{\mathrm{a}}$.

\begin{tabular}{|c|c|c|c|c|c|}
\hline \multicolumn{2}{|c|}{ Treatment } & \multicolumn{4}{|c|}{ Woolly fruit (\%) } \\
\hline & & \multicolumn{4}{|c|}{ Period at $23.0^{\circ} \mathrm{C}\left( \pm 3.0^{\circ} \mathrm{C}\right)$ and $75.0 \%( \pm 5.0 \%) \mathrm{RH}$} \\
\hline $\mathrm{GA}_{3}$ & Storage & $6 \mathrm{~h}$ & 2 days & 4 days & 6 days \\
\hline Control & $\mathrm{CS}^{\mathrm{b}}$ & $24.5 a^{c}$ & $94.2 \mathrm{a}$ & $94.2 \mathrm{a}$ & $48.5 \mathrm{a}$ \\
\hline Control & $\mathrm{CA} / \mathrm{CS}^{\mathrm{d}}$ & $0.0 \mathrm{~b}$ & $23.5 \mathrm{~b}$ & $23.2 \mathrm{~b}$ & $0.0 \mathrm{C}$ \\
\hline T1 & CS & $0.0 \mathrm{~b}$ & $28.6 \mathrm{~b}$ & $9.5 \mathrm{~b}$ & $19.8 \mathrm{~b}$ \\
\hline
\end{tabular}

a Peaches were harvested when the fruit colour was light green, corresponding to the pre-climacteric stage, between S3 I and S3 II, as described by Trainotti et al. (2003).

b Cold storage $(\mathrm{CS}): 1.0^{\circ} \mathrm{C}\left( \pm 1.0^{\circ} \mathrm{C}\right), 92.0 \%( \pm 5.0 \%)$ relative humidity $(\mathrm{RH})$.

c Means of treatment $(n=120)$ in the same column, followed by different letters, are statistically different according to Duncan's test ( $p \leq 0.05$ ).

${ }^{d}$ Controlled atmosphere (CA/CS): $2 \mathrm{kPa}$ of $\mathrm{O}_{2}$, and $5 \mathrm{kPa}$ of $\mathrm{CO}_{2}, 1.0^{\circ} \mathrm{C}\left( \pm 1.0^{\circ} \mathrm{C}\right)$ 


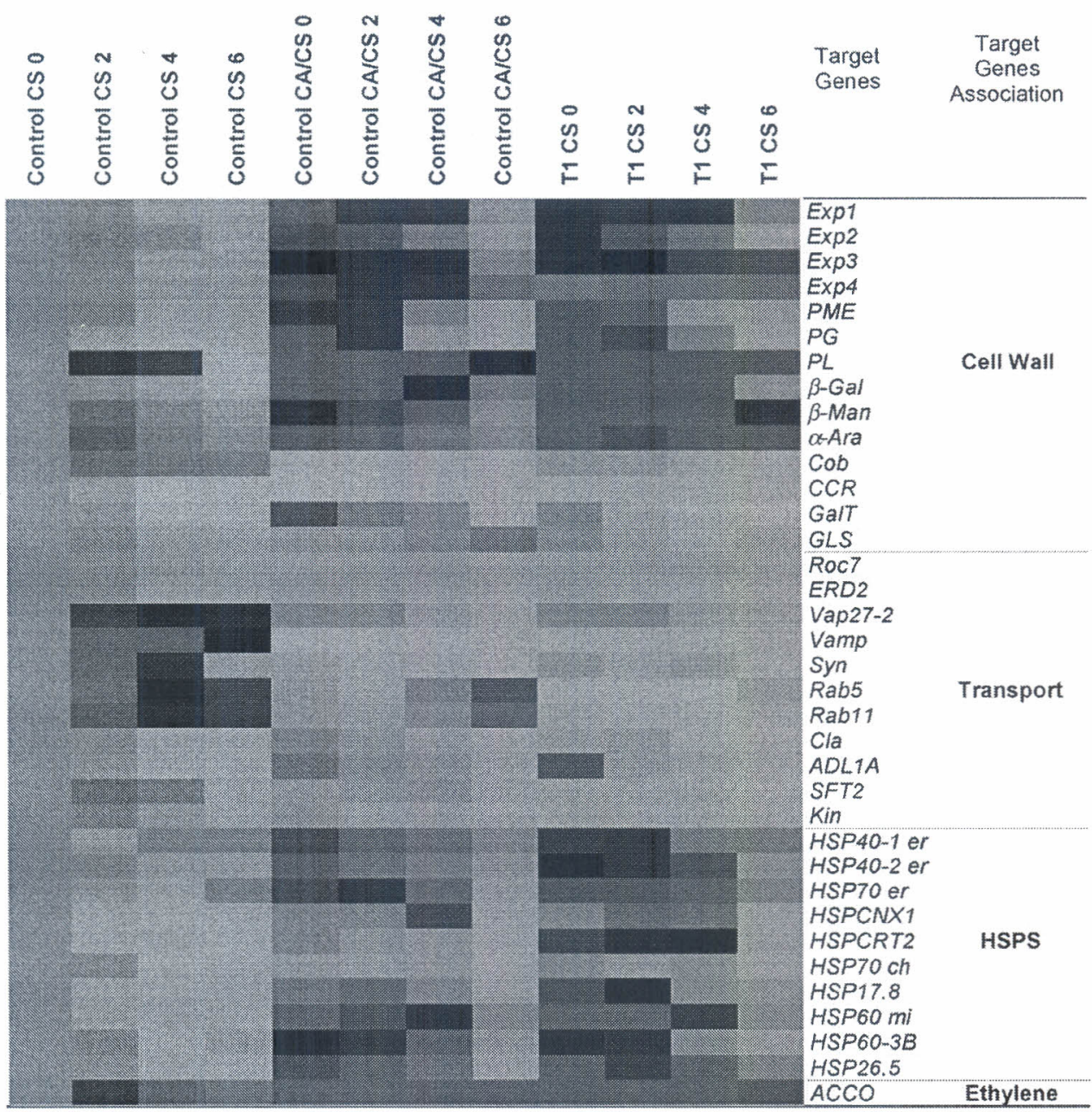

Fig. 1. Relative mRNA abundance in Chiripá peach fruit, harvested from untreated trees (Control) and from trees sprayed with GA 3 at the beginning of pit hardening (T1), stored for 30 days, under cold storage (CS) or controlled atmosphere/cold storage (CA/CS), and finally removed from storage and exposed to 23.0 ( $\mathrm{C}\left( \pm 3.0{ }^{\circ} \mathrm{C}\right.$ ) and $75.0 \%$ $( \pm 5.0 \%) \mathrm{RH}$, for $6 \mathrm{~h}(0), 2,4$ and 6 days. mRNA abundance is represented on a scale of $0-30$, using the Multi Experiment Viewer (TIGR MeV) software (Saeed et al., 2003). The lower end of the scale (light green colour) indicates the lowest mRNA abundance; black colour in the middle of the scale represents mRNA abundance 5 times higher than the light green end; and red colour in the upper end of the scale represents the highest mRNA abundance, 30 times higher than the lowest. mRNA abundance of each gene from Control CS fruit at $6 \mathrm{~h}$ served as the baseline for determining relative RNA levels. Cold storage (CS): $1.0{ }^{\circ} \mathrm{C}\left( \pm 1.0^{\circ} \mathrm{C}\right), 92.0 \%( \pm 5.0 \%)$ relative humidity (RH). Controlled atmosphere (CA/CS): $2 \mathrm{kPa}$ of $\mathrm{O}_{2}$, and $5 \mathrm{kPa}$ of $\mathrm{CO}_{2}, 1.0^{\circ} \mathrm{C}\left( \pm 1.0^{\circ} \mathrm{C}\right), 92.0 \%( \pm 5.0 \%) \mathrm{RH}$.

mRNA abundance of HSP40-1er, HSP40-2er, HSPCRT2, HSP17.8ch, Exp4, $\beta$-Man, $\alpha$-Ara, GalT and ADL1A, positively related to woolliness prevention, had different mRNA abundance profiles between Control CA/CS and T1 CS. mRNA abundance of HSPS, ADL1A, $\alpha$-Ara and $\beta$-Mun was higher in $\mathrm{GA}_{3}$-treated peaches, whereas, mRNA abundance of Exp4 and GalT was higher in Control CA/CS peaches.

mRNA abundance of transport associated genes Roc7, ERD2, Cla, SFT2, Kin, of HSP70ch and of cell wall structure associated genes $C o b, G L S$ and $C C R$, were generally unaffected by $\mathrm{GA}_{3}$ treatment or by storage condition during ripening, but Vap27-2, Vamp, Syn, Rab5 and Rab11, vesicle transport associated genes, had higher relative abundance of mRNAs in woolly fruit (Control (S).

In woolly fruit (Control CS), ACCO mRNA abundance was lower than in untreated CA/CS and T1 CS fruit (Fig. 1) and protein was not detected (Fig. 2). In contrast, high relative abundance of ACCO $\mathrm{mRNA}$ and protein were detected and classic climacteric behaviour was observed in Control CA/CS and T1 CS peaches.
In woolly fruit all measured proteins were detected in lower amounts (Fig. 2). PME, PG, $\beta$-Gal and PL proteins (Fig. 2) were detected during ripening at room temperature in treatments preventing woolliness (Control CA/CS and T1 CS) before the onset of the climacteric stage (Table 4 ). The differences between protein abundance between Control CA/CS and T1 CS rely on PL which started to accumulate later in Control CA/CS when compared to T1 CS, and PME which was absent during day 4 in T1 CS and present in Control CA/CS. Moreover $\beta$-Man and $\alpha$-Ara proteins were only detected during days 4 and 6 during ripening in gibberellic acid treated fruit (Fig. 2).

\section{Discussion}

Pre-harvest application of $\mathrm{GA}_{3}$ to peach (Zilkah et al., 1997; Ju et al., 1999; Martinez-Romero et al., 2000; Amarante et al., 2005) and other fruit, such as persimmon (D. kaki L.)(Ben-Arie et al., 1996; 


\section{Table 4}

Ethylene production of Chiripá peach fruit, harvested from untreated trees (Control) and from trees sprayed with $\mathrm{GA}_{3}$ at the beginning of pit hardening (T1), stored for 30 days, under cold storage (CS) or controlled atmosphere (CA/CS), and finally removed from storage and exposed to $23.0^{\circ} \mathrm{C}\left( \pm 3.0^{\circ} \mathrm{C}\right)$ and $75.0 \%( \pm 5.0 \%) \mathrm{RH}$, for $6 \mathrm{~h}, 2,4$ and 6 days $^{\mathrm{a}}$.

\begin{tabular}{|c|c|c|c|c|c|}
\hline \multicolumn{2}{|c|}{ Treatment } & \multicolumn{4}{|c|}{ Ethylene production $\left(\mathrm{nLg}^{-1} \mathrm{~h}^{-1}\right)$} \\
\hline $\mathrm{GA}_{3}$ & Storage & $6 \mathrm{~h}$ & 2 days & 4 days & 6 days \\
\hline Control & $C S^{b}$ & $0.93 a^{c}$ & $1.23 \mathrm{c}$ & $1.24 \mathrm{c}$ & $0.59 \mathrm{~b}$ \\
\hline Control & $\mathrm{CA} / \mathrm{CS}^{\mathrm{d}}$ & $0.87 a$ & $5.52 b$ & $15.21 \mathrm{~b}$ & $3.36 a$ \\
\hline $\mathrm{T} 1$ & CS & $1.06 \mathrm{a}$ & $11.65 \mathrm{a}$ & $24.53 a$ & $4.80 a$ \\
\hline
\end{tabular}

a The peaches were harvested when the fruit colour was light green, corresponding to the pre-climacteric stage, between S3 I and S3 II, as described by Trainotti et al. (2003).

b Cold storage $(\mathrm{CS}): 1.0^{\circ} \mathrm{C}\left( \pm 1.0^{\circ} \mathrm{C}\right), 92.0 \%( \pm 5.0 \%)$ relative humidity (RH).

c Means of treatment $(n=3)$ in the same column, followed by different letters, are statistically different according to Duncan's test ( $p \leq 0.05)$.

d Controlled atmosphere (CA/CS): $2 \mathrm{kPa}$ of $\mathrm{O}_{2}$, and $5 \mathrm{kPa}$ of $\mathrm{CO}_{2}, 1.0^{\circ} \mathrm{C}\left( \pm 1.0^{\circ} \mathrm{C}\right)$, $92.0 \%( \pm 5.0 \%) \mathrm{RH}$.

Ferri et al., 2004), tangerine (C. reticulata L.) (Marur et al., 1999) and cherry (Prunus avium L.) (Kappel and MacDonald, 2002; Usenik et al., 2005), can extend the ripening cycle and as a consequence in some cases increase fruit size. In this study, a pre-harvest spray with $\mathrm{GA}_{3}$ did not extend the ripening cycle of Chiripá peaches but induced an increase in fruit size and mass. Fruit from all treatments reached the same ripening stage at the same time without showing any differences in physicochemical characteristics (Table 2). At harvest, fruit showed pre-climacteric ripening with an ethylene production ten times less than that found for peaches at the climacteric stage (Girardi et al., 2005).

However, an important technological improvement was obtained here, with the increase in fruit size and mass upon $\mathrm{GA}_{3}$ application, leading to a $47 \%$ gain in productivity per plant (51-75 kg per plant) equivalent to increasing productivity from 25,500 to $37,740 \mathrm{~kg} \mathrm{ha}^{-1}$. It has been shown that agronomic practices that contribute to an increase in fruit size in Chiripá peaches (i.e. thinning) result in higher susceptibility to woolliness (Rombaldi et al., 2002). Interestingly, the increase in fruit size did not negatively affect peach preservation, with low levels of woolliness after CS.

Gibberellic acid has been associated with the prevention of many physiological postharvest disorders (Zilkah et al., 1997; Ju et al., 1999; Martinez-Romero et al., 2000; Kappel and MacDonald, 2002; Amarante et al., 2005; Usenik et al., 2005). According to Yamaguchi and Kamiya (2000), responses derived from exogenous GA supply are associated with synthesis deficiency and/or higher sensitivity to signal reception and transduction. Physiological responses observed in Chiripá peaches upon $\mathrm{GA}_{3}$ treatment indicate a possible deficit of this hormone. In addition, Chiripá peaches were only responsive to $\mathrm{GA}_{3}$ when sprayed prior to pit hardening, leading to a size increase and preventing woolliness upon cold storage.

Woolliness occurrence in $\mathrm{GA}_{3}$-treated peaches (T1 CS) was as low as in untreated control peaches stored under CA/CS (Table 3). Upon extension of the ripening period, it was observed that woolly fruit (Control CS) became juicy again (Table 3). According to Lurie and Crisosto (2005), this apparent restoration of free juice is due to tissue breakdown and senescence. Therefore, a decrease in occurrence of woolliness seen in late ripening does not represent an actual reduction of the problem but a further decay of the fruit. In addition, signs of internal browning observed 6 days after CS confirmed the senescence of the fruit at that point.

In order to understand the molecular mechanisms associated with the physiological responses to $\mathrm{GA}_{3}$ application and storage conditions, relative mRNA abundance of a set of genes putatively involved in endomembrane transport via endoplasmic reticulum (ER), Golgi complex (GC) and vesicles, cell wall structure and disassembly, stress response (heat shock proteins) and ethylene synthesis were investigated.

Fruit from treatments with lower occurrence of woolliness (Control CA/CS and T1 CS) developed a classical climacteric behaviour during ripening, while fruit with high occurrence of woolliness (Control CS) did not develop climacteric production of ethylene (Table 4 ). This response might be related to low relative abundance of ACCO mRNA (Fig. 1) and absence of ACCO protein observed in woolly fruit (Fig. 2). In contrast, high relative abundance of ACCO mRNA and protein were detected and classic climac-
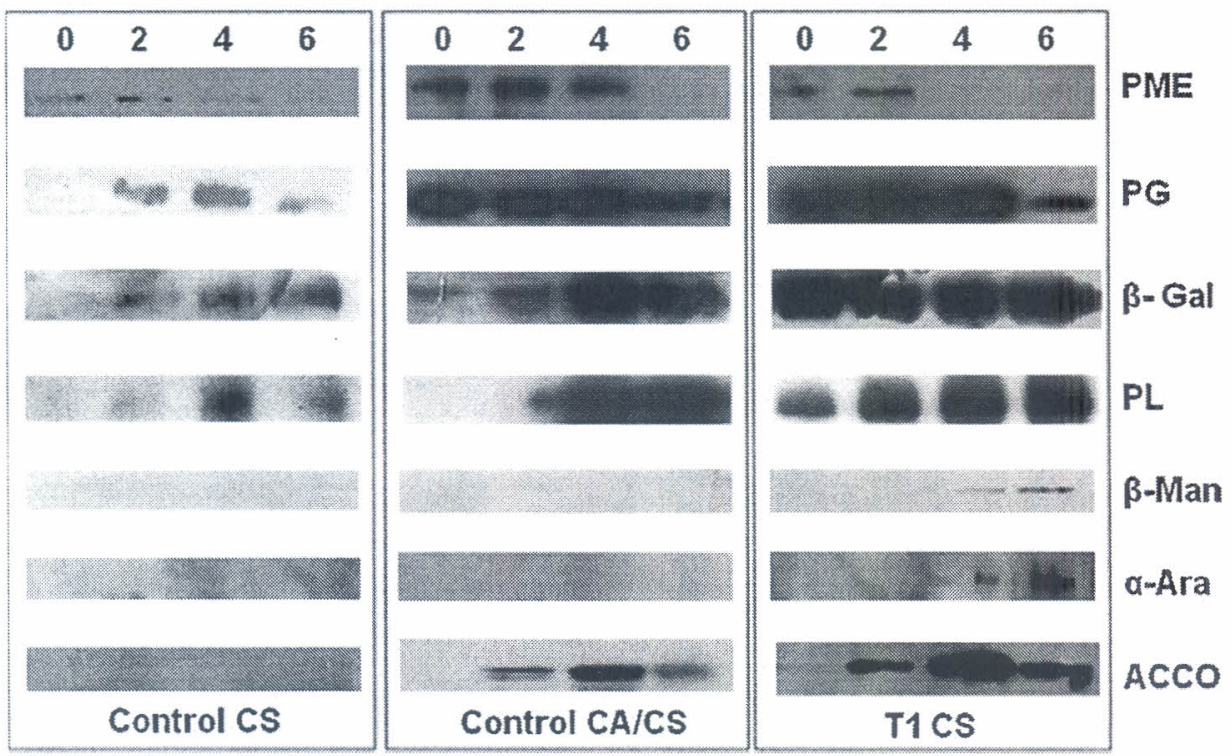

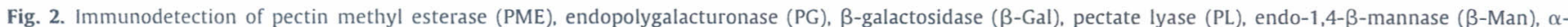

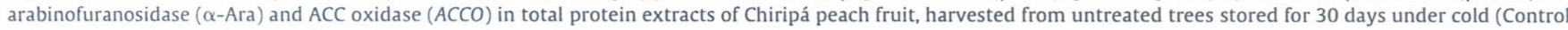

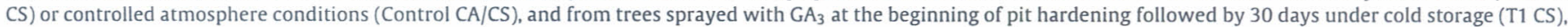
and finally removed from storage and exposed to $23.0^{\circ} \mathrm{C}\left( \pm 3.0^{\circ} \mathrm{C}\right)$ and $75.0 \%( \pm 5.0 \%) \mathrm{RH}$, for $6 \mathrm{~h}(0), 2,4$ and 6 days. 
teric behaviour was observed in Control CA/CS and T1 CS peaches, suggesting ethylene involvement in woolliness prevention. These findings agree with Giehl et al. (2008) who demonstrated that juiciness in peach is an ethylene-dependent process, with CA/CS storage allowing normal ethylene production and reduced woolliness. Moreover, Girardi et al. (2005) observed that supplying ethylene during CS prevents woolliness, while inhibiting ethylene with 1MCP increases this chilling injury. In this study, the transcription and translation of genes encoding cell wall proteins were not completely ethylene-dependent. PME, PG, $\beta$-Gal and PL mRNAs (Fig. 1) and proteins (Fig. 2) were detected before the onset of the climacteric stage (Table 4), corroborating transcript findings of Trainotti et al. (2003). In addition, Nishiyama et al. (2007) found that two out of three PGs are ethylene-dependent in climacteric melons.

All genes studied here, putatively coding for cell wall associated proteins, have a signal peptide, suggesting that transport to the apoplast occurs via ER and GC, as predicted using iPSORT (Bannai et al., 2002), TargetP (Emanuelsson et al., 2000) and SignalP (Nielsen et al., 1997) software. Therefore, it is expected that protection of the ER, GC and vesicular endomembrane system is essential for the appropriate transport and folding of proteins to occur, in agreement with recent results by Vizoso et al. (2009) and Ogundiwin et al. (2008). The higher relative expression profile of ER genes (HSP40-1er, HSP40-2er, HSP70er, HSPCNX1) in peach from Control CA/CS and T1 CS agrees with this hypothesis. Moreover, recently, Sun et al. (2010) found three cytosolic small heat shock proteins with an important role in chilling tolerance in stonefruit. The potential role of these genes in regulating cell homeostasis under abiotic stresses has been previously observed in other species (Pratt and Toft, 2003; Iwata et al., 2008; Mueller et al., 2008; Su and $\mathrm{Li}, 2008) . \mathrm{GA}_{3}$ treatment also induced high relative expression of expansins (Exp1, Exp2 and Exp3), PME, PG, PL, $\beta$-Gal, $\beta$-Man and $\alpha$ Ara genes (Fig. 1) coding for cell wall targeted proteins transported via ER and GC (Nakashima et al., 2004; Lycett, 2008). Moreover, preharvest $\mathrm{GA}_{3}$ treatment contributed to a higher mRNA abundance of HSP genes, associated with the defense of chloroplasts (HSP17.8ch) (Millar et al., 2006; Jarvis, 2008; Kahlau and Bock, 2008) and mitochondria (HSP60mi, HSP60-3Bmi and HSP26.5 mi) (Lister et al., 2004; Radhamony and Theg, 2006), indicative of better homeostasis of the metabolism of these organelles in peaches with adequate ripening. According to González-Agüero et al. (2008), peaches with normal ripening generally show up-regulation of genes encoding proteins associated with vesicle transport. In contrast, in Chiripá peaches, vesicle transport associated genes Vap27-2, Vamp, Syn, Rab5 and Rab11 showed high relative mRNA abundance in woolly fruit (Control CS) (Fig. 1). Rab11 involvement in PME and PG transport and fruit softening has been previously demonstrated in tomato (Lu et al., 2001). Similarly, Lycett (2008) cited Rab5 participation in the formation of endosomes, with increased transcription during fruit ripening. Additionally, Appezzato-da-Glória et al.(2004) in cytological studies of woolly fruit, observed a macroendocytosis process with endosome individualization containing cell wall materials, probably pectins, suggesting an endocytic transport associated with woolliness.

Although an inverse relationship between the expression of some vesicular genes and the prevention of woolliness was observed, a direct relationship between the mRNA abundance of genes associated with ethylene synthesis, ER, mitochondria and chloroplast protection, and of cell wall metabolism occurred (Fig. 1). The lower relative abundance of proteins involved in cell wall metabolism observed in Control CS (Fig. 2) is in agreement with the low relative mRNA abundance (Fig. 1), indicating a coordination between transcription and translation of these genes.

mRNA abundance of Cob, GLS, CCR, Roc7, ERD2, Cla, SFT2, Kin and HSP70ch genes was not affected by $\mathrm{GA}_{3}$ treatment or by storage condition during ripening (Fig. 1). HSP40-1er, HSP40-2er,
HSPCRT2, HSP17.8ch, Exp4, $\beta$-Man, $\alpha$-Ara, GalT and ADL1A, positively related to woolliness prevention, had different profiles between Control CA/CS and T1 CS. While HSPS, ADL1A and $\alpha$-Ar $a$ and $\beta$-Man showed higher relative expression in $\mathrm{GA}_{3}$-treated peach, Exp4 and GalT expression was high in Control CA/CS peach. Although both treatments prevented woolliness, differential mRNA and protein abundance suggest differences in the molecular and biochemical mechanisms of woolliness prevention induced by $\mathrm{GA}_{3}$ and $\mathrm{CA} / \mathrm{CS}$.

In summary, $\mathrm{GA}_{3}$ treatment followed by cold storage (T1 CS) proved as efficient as storage of peach under controlled atmosphere conditions (Control CA/CS) in providing normal ripening and preventing woolliness in Chiripá peaches. $\mathrm{GA}_{3}$ treatment, despite not delaying ripening, induced an increase in fruit size and mass when applied at the beginning of pit hardening. The molecular responses associated with woolliness prevention in common between $\mathrm{GA}_{3}$ and CA/CS treatments, involved high relative mRNA abundance of genes associated with cell wall metabolism, ER, chloroplast and mitochondria HSPS, and ACCO and lower relative mRNA abundance of vesicle transport related genes (Vap27-2, Vamp, Syn, Rab5 and Rab11) when compared to woolly fruit. Although both treatments prevented woolliness, differential abundance of mRNA (HSP401er, HSP40-2er, HSPCTR2, HSP17.8ch, Exp4, $\beta$-Man, $\alpha$-Ara, GalT and $A D L 1 A$ ) and protein ( $\beta$-Man and $\alpha$-Ara) suggest different molecular and biochemical mechanisms induced by $\mathrm{GA}_{3}$ and $C A$.

Studies should follow to further characterize the protective mechanisms induced by $\mathrm{GA}_{3}$ treatment and controlled atmosphere storage of peach. Currently, a pre-harvest evaluation of gene expression in peach fruit treated with $\mathrm{GA}_{3}$ is under way to characterize early changes leading to woolliness or woolliness prevention.

\section{Acknowledgements}

To Prof. Odir Antonio Dellagostin and Dr. Sibele Borsuk (Centro de Biotecnologia da Universidade Federal de Pelotas) for their help with antibody production. This work was supported by the Brazilian Ministry of Education (Capes) and Ministry of Science and Technology (CNPq number 470480/2007-6 and 301721/2007-6).

\section{References}

Amarante, C.V.T.D., Drehmer, A.M.F., Souza, F.D., Francescatto, P., 2005. A pulverização pré-colheita com ácido giberélico $\left(\mathrm{GA}_{3}\right)$ e aminoetoxivinilglicina (AVG) retarda a maturação e reduz as perdas de frutos na cultura do pessegueiro. Rev. Bras. Frutic. 27, 1-5.

Appezzato-da-Glória, B., Bron, I.U., Machado, S.R., 2004. Lanosidade em cultivares de pêssego (Prunus persica (L.) Batsch): estudos anatômicos e ultra-estruturais. Rev. Bras. Bot. 27, 55-61.

Bannai, H., Tamada, Y., Maruyama, O., Nakai, K., Miyano, S., 2002. Extensive feature detection of $\mathrm{N}$-terminal protein sorting signals. Bioinformatics 18, 298-305.

Ben-Arie, R., Saks, Y., Sonego, L., Frank, A., 1996. Cell wall metabolism in gibberellintreated persimmon fruits. Plant Growth Regul. 19, 25-33.

Benson, D.A., Karsch-Mizrachi, I., Lipman, D.J., Ostell, J., Wheeler, D.L., 2005. GenBank. Nucl. Acids Res. 33, D34-D38.

Bradford, M.M., 1976. A rapid and sensitive method for the quantitation of microgram quantities of protein utilizing the principle of protein-dye binding. Anal. Biochem. 72, 248-254.

Brummell, D.A., Dal Cin, V., Lurie, S., Crisosto, C.H., Labavitch, J.M., 2004. Cell wall metabolism during the development of chilling injury in cold-stored peach fruit: association of mealiness with arrested disassembly of cell wall pectins. J. Exp. Bot. 55, 2041-2052.

Emanuelsson, O., Nielsen, H., Brunak, S., von Heijne, G., 2000. Predicting subcellular localization of proteins based on their $\mathrm{N}$-terminal amino acid sequence. J. Mol. Biol. 300, 1005-1016.

Ferri, V.C., Rinaldi, M.M., Silva, J.A., Luchetta, L., Marini, L., Rombaldi, C.V., 2004. Ácido giberélico no retardamento da maturação de caquis (Diospyrus kaki, L.), cultivar Fuyu. Ciênc. Tecnol. Aliment. 24, 1-5.

Girardi, C.L., Corrent, A.R., Lucchetta, L., Zanuzo, M.R., da Costa, T.S., Brackmann, A., Twyman, R.M., Nora, F.R., Nora, L., Silva, J.A., Rombaldi, C.V., 2005. Effect of ethylene, intermittent warming and controlled atmosphere on postharvest quality and the occurrence of woolliness in peach (Prunus persica cv. Chiripá) during cold storage. Postharvest Biol. Technol. 38, 25-33.

González-Agüero, M., Pavez, L., Ibanez, F., Pacheco, I., Campos-Vargas, R., Meisel, L.A., Orellana, A., Retamales, J., Silva, H., Gonzalez, M., Cambiazo, V., 2008. Identification of woolliness response genes in peach fruit after post-harvest treatments. J. Exp. Bot. 59, 1973-1986. 
Hu, J.H., Mitchum, M.G., Barnaby, N., Ayele, B.T., Ogawa, M., Nam, E., Lai, W.C., Hanada, A., Alonso, J.M., Ecker, J.R., Swain, S.M., Yamaguchi, S., Kamiya, Y., Sun, T.P., 2008. Potential sites of bioactive gibberellin production during reproductive growth in Arabidopsis. Plant Cell 20, 320-336.

Iwata, Y., Fedoroff, N.V., Koizumi, N., 2008. Arabidopsis bZIP60 is a proteolysisactivated transcription factor involved in the endoplasmic reticulum stress response. Plant Cell 20, 3107-3121.

Jarvis, P., 2008. Targeting of nucleus-encoded proteins to chloroplasts in plants. New Phytol. 179, 257-285

Ju, Z.G., Duan, Y.S., Ju, Z.Q., 1999. Combinations of GA(3) and AVG delay fruit maturation, increase fruit size and improve storage life of 'Feicheng' peaches. J. Hortic. Sci. Biotechnol. 74, 579-583.

Kahlau, S., Bock, R., 2008. Plastid transcriptomics and translatomics of tomato fruit development and chloroplast-to-chromoplast differentiation: chromoplast gene expression largely serves the production of a single protein. Plant Cell 20, 856-874.

Kappel, F., MacDonald, R.A., 2002. Gibberellic acid increases fruit firmness, fruit size, and delays maturity of 'sweetheart' sweet cherry. J. Am. Pomolog. Soc. 56, 219-222.

Lister, R., Chew, O., Lee, M.N., Heazlewood, J.L., Clifton, R., Parker, K.L., Millar, A.H., Whelan, J., 2004. A transcriptomic and proteomic characterization of the Arabidopsis mitochondrial protein import apparatus and its response to mitochondrial dysfunction. Plant Physiol. 134, 777-789.

Livak, K.J., Schmittgen, T.D., 2001. Analysis of relative gene expression data using real-time quantitative PCR and the 2(T)(-Delta Delta C) method. Methods 25 , 402-408.

Lu, C.G., Zainal, Z., Tucker, G.A., Lycett, G.W., 2001. Developmental abnormalities and reduced fruit softening in tomato plants expressing an antisense Rab11 GTPase gene. Plant Cell 13, 1819-1833.

Lurie, S., Crisosto, C.H., 2005. Chilling injury in peach and nectarine. Postharvest Biol. Technol. 37, 195-208.

Lycett, G., 2008. The role of Rab GTPases in cell wall metabolism. J. Exp. Bot. 59, $4061-4074$

Martinez-Romero, D., Valero, D., Serrano, M., Burlo, F., Carbonell, A., Burgos, L., Riquelme, F., 2000. Exogenous polyamines and gibberellic acid effects on peach (Prunus persica L.) storability improvement. J. Food Sci. 65, 288-294.

Martínez, G.A., Chaves, A.R., Añón, M.C., 1994. Effect of gibberellic acid on ripening of strawberry fruits (Fragaria annanassa Duch.). J. Plant Growth Regul. 13, 87-91.

Marur, C.J., Stenzel, N.M.C., Rampazzo, E.F., Scholz, M.B.S., 1999. Ácido Giberélico $\left(\mathrm{GA}_{3}\right)$ e maturação de frutos das tangerinas 'Mexerica Montenegrina'e 'Poncã'. Sci. Agric. 56, 517-521.

Millar, A.H., Whelan, J., Small, I., 2006. Recent surprises in protein targeting to mitochondria and plastids. Curr. Opin. Plant Biol. 9, 610-615.

Mueller, S., Hilbert, B., Dueckershoff, K., Roitsch, T., Krischke, M., Mueller, M.J., Berger, S. 2008. General detoxification and stress responses are mediated by oxidized lipids through TGA transcription factors in Arabidopsis. Plant Cell 20, 768-785.

Nakashima, J., Endo, S., Fukuda, H., 2004. Immunocytochemical localization of polygalacturonase during tracheary element differentiation in Zinnia elegans. Planta 218, 729-739.

Nielsen, H., Engelbrecht, J., Brunak, S., vonHeijne, G., 1997. Identification of prokaryotic and eukaryotic signal peptides and prediction of their cleavage sites. Protein Eng. 10, 1-6.

Nishiyama, K., Guis, M., Rose, J.K.C., Kubo, Y., Bennett, K.A., Lu, W.J., Kato, K., Ushijima, K., Nakano, R., Inaba, A., Bouzayen, M., Latche, A., Pech, J.C., Bennett, A.B., 2007. Ethylene regulation of fruit softening and cell wall disassembly in Charentais melon. J. Exp. Bot. 58, 1281-1290.

Ogundiwin, E.A., Marti, C., Forment, J., Pons, C., Granell, A., Gradziel, T.M., Peace, C.P., Crisosto, C.H., 2008. Development of ChillPeach genomic tools and identification of cold-responsive genes in peach fruit. Plant Mol. Biol. 68, 379-397.

Pratt, W.B., Toft, D.O., 2003. Regulation of signaling protein function and trafficking by the hsp90/hsp70-based chaperone machinery. Exp. Biol. Med. 228, 111-133.
Radhamony, R.N., Theg, S.M., 2006. Evidence for an ER to Golgi to chloroplast protein transport pathway. Trends Cell Biol. 16, 385-387.

Ramos, C.R.R., Abreu, P.A.E., Nascimento, A.L.T.O., Ho, P.L., 2004. A high-copy T7 Escherichia coli expression vector for the production of recombinant proteins with a minimal N-terminal his-tagged fusion peptide. Braz. J. Med. Biol. Res. 37, 1103-1109.

Rombaldi, C., Lelievre, J.M., Latche, A., Petitprez, M., Bouzayen, M., Pech, J.C., 1994. Immunocytolocalization of 1-aminocyclopropane-1-carboxylic acid oxidase in tomato and apple fruit. Planta 192, 453-460.

Rombaldi, C.V., Silva, J.A., Parussolo, A., Lucchetta, L., Zanuzo, M.R., Girardi, C.L., Cantillano, R.F.F., 2002. Armazenamento de pêssegos (Prunus persica L.), cultivar Chiripá, em atmosfera controlada. Ciência Rural 31, 43-47.

Rosenvasser, S., Mayak, S., Friedman, H., 2006. Increase in reactive oxygen species (ROS) and in senescence-associated gene transcript (SAG) levels during darkinduced senescence of Pelargonium cuttings, and the effect of gibberellic acid. Plant Sci. 170, 873-879.

Saeed, A.I., Sharov, V., White, J., Li, J., Liang, W., Bhagabati, N., Braisted, J., Klapa, M., Currier, T., Thiagarajan, M., Sturn, A., Snuffin, M., Rezantsev, A., Popov, D., Ryltsov, A., Kostukovich, E., Borisovsky, I., Liu, Z., Vinsavich, A., Trush, V., Quackenbush, J., 2003. TM4: A free, open-source system for microarray data management and analysis. Biotechniques 34, 374.

Sambrook, J., Fritsch, E.J., Maniatis, T. (Eds.), 1989. Molecular Cloning: A Laboratory Manual. Cold Spring Harbor Laboratory Press, New York, USA.

Su, P.H., Li, H.M., 2008. Arabidopsis stromal 70-kD heat shock proteins are essential for plant development and important for thermotolerance of germinating seeds. Plant Physiol. 146, 1231-1241.

Sun, J.-H., Chen, J.-Y., Kuanga, J.-F., Chena, W.-X., Lu, W.-J., 2010. Expression of sHSP genes as affected by heat shock and cold acclimation in relation to chilling tolerance in plum fruit. Postharvest Biol. Technol. 55, 91-96.

Thomas, S.G., Rieu, I., Steber, C.M., 2005. Gibberellin metabolism and signaling. In: Litwack, G. (Ed.), Gibberellin Metabolism and Signaling, Plant Hormones, 72. Elsevier Academic Press Inc., Toluca Lake, CA, pp. 289-338.

Trainotti, L., Zanin, D., Casadoro, G., 2003. A cell wall-oriented genomic approach reveals a new and unexpected complexity of the softening in peaches. J. Exp. Bot. 54, 1821-1832.

Trainotti, L., Bonghi, C., Ziliotto, F., Zanin, D., Rasori, A., Casadoro, G., Ramina, A., Tonutti, P., 2006. The use of microarray mu PEACH1.0 to investigate transcriptome changes during transition from pre-climacteric to climacteric phase in peach fruit. Plant Sci. 170, 606-613.

Usenik, V., Kastelec, D., Stampar, F., 2005. Physicochemical changes of sweet cherry fruits related to application of gibberellic acid. Food Chem. 90, 663-671.

Vizoso, P., Meisel, L.A., Tittarelli, A., Latorre, M., Saba, J., Caroca, R., Maldonado, J., Cambiazo, V., Campos-Vargas, R., Gonzalez, M., Orellana, A., Silva, H., 2009. Comparative EST transcript profiling of peach fruits under different post-harvest conditions reveals candidate genes associated with peach fruit quality. BMC Genomics 10, 423, http://www.biomedcentral.com/1471-2164/10/423.

Yamaguchi, S., Kamiya, Y., 2000. Gibberellin biosynthesis: Its regulation by endogenous and environmental signals. Plant Cell Physiol. 41, 251-257.

Zhou, H.W., Lurie, S., Lers, A., Khatchitski, A., Sonego, L., Ben Arie, R., 2000. Delayed storage and controlled atmosphere storage of nectarines: two strategies to prevent woolliness. Postharvest Biol. Technol. 18, 133-141.

Zilkah, S., Lurie, S., Lapsker, Z., Zuthi, Y., David, I., Yesselson, Y., Antman, S., Ben Arie, R., 1997. The ripening and storage quality of nectarine fruits in response to preharvest application of gibberellic acid. J. Hortic. Sci. 72, 355-362.

Giehl, R.F.H., Brackmann, A., Eisermann, A.C., Weber, A., Neuwald, D.A., 2008. CA affects juiciness in peaches due to an earlier post-storage ethylene production. In: J. Streif and R. McCormick (Eds.), International Conference on Ripening Regulation and Postharvest Fruit Quality, 12-13 November 2007, Weingarten, Germany. Acta Horticulturae (ISHS). 796, pp. 185-189.

Zonta, E.P., Machado, A.A., 1991. Mannual do SANEST: Sistema de análise estatística para microcomputadores. DMEC/IFM/UFPEL, Pelotas, RS, Brasil. 